\title{
Emendation of Xanthøbacter flavus as a Motile Species
}

\author{
H. KEITH REDING, ${ }^{1} \dagger$ GRACE L. M. CROES, ${ }^{2}$ LUBBERT DIJKHUIZEN, ${ }^{2}$ \\ AND JUERGEN WIEGEL ${ }^{1 *}$ \\ Department of Microbiology and Center for Biological Resource Recovery, Biological Sciences Building, \\ University of Georgia, Athens, Georgia 30602, ${ }^{1}$ and Department of Microbiology, \\ University of Groningen, Kerlaan 30, 9751 NN Haren, The Netherlands ${ }^{2}$
}

\begin{abstract}
Xanthobacter flavus $301^{\mathrm{T}}$ ( $\mathrm{T}=$ type strain) and other strains, including H4-14, both of which were previously described as nonmotile, were reproducibly motile and peritrichously flagellated during the $\log$ phase when they were cultured in medium lacking tricarboxylic acid cycle intermediates. Therefore, the species description is emended to include motility and flagellation. Similarly, Xanthobacter autotrophicus was found to be flagellated and motile, but this finding was not consistently reproducible and was mainly found with the mutant strain $\mathrm{Fe}^{-\mathrm{s}}$.
\end{abstract}

Currently, the genus Xanthobacter (10) consists of three species, Xanthobacter autotrophicus (the type species), Xanthobacter flavus, and Xanthobacter agilis. Strains of $X$. autotrophicus $(11)$ and $X$. flavus $(3,5)$ have been described as being nonmotile, whereas strains of $X$. agilis have been described as being motile (2). $X$. flavis is the only biotin-requiring species. Typically, new Xanthobacter isolates are classified tentatively into one of the three Xanthobacter species on the basis of motility and biotin requirement (12). Recently, Reding et al. reported that Xanthobacter strains isolated from the roots of rice were motile but differed morphologically and physiologically from strains of $X$. agilis $(7,8)$. Meijer et al. have described a Xanthobacter strain, strain $25 \mathrm{a}$, that is motile and requires biotin (6).

During routine growth experiments, we observed that $X$. flavus was motile under certain culture conditions. Motility depended on the growth phase and the carbon source (Table 1). In general, growth in the presence of tricarboxylic acid cycle intermediates produced nonmotile cells, whereas growth on alcohols or transfer of washed cells to medium lacking tricarboxylic acid cycle intermediates resulted in motile cells. Growth on $\mathrm{H}_{2}-\mathrm{CO}_{2}$, glutamate, or glutamine also produced nonmotile cells. However, we emphasize the effect of tricarboxylic acid cycle intermediates because

TABLE 1. Effect of carbon source on the motility of $X$. flavus and $X$. agilis ${ }^{a}$

\begin{tabular}{lcc}
\hline \multicolumn{1}{c}{ Substrates } & \multicolumn{2}{c}{ Motility of: } \\
\cline { 2 - 3 } & $\begin{array}{c}\text { X. agilis } \\
\text { SA35 }\end{array}$ & $\begin{array}{c}X . \text { flavus } \\
301^{\mathrm{T}}\end{array}$ \\
\hline $\begin{array}{l}\text { Citrate, fumarate, malate, succinate, } \\
\text { glutamate, glutamine, yeast }\end{array}$ & + & - \\
$\begin{array}{l}\text { extract, } \mathrm{H}_{2}-\mathrm{CO}_{2} \\
\begin{array}{l}\text { Methanol, ethanol, } n \text {-propanol, } \\
\text { isopropanol, butanol, gluconate }\end{array}\end{array}$ & + & + \\
\hline
\end{tabular}

${ }^{a}$ Cultures were grown to late log phase and transferred $(2 \%, \mathrm{vol} / \mathrm{vol})$ to test medium containing a carbon source at a concentration of $0.2 \%$ (wt/vol). Motility was determined by examining wet mounts with a Vanox phasecontrast light microscope (Olympus, Hyde Park, Pa.). Only the substrates which supported growth of both species were used for comparison. + , cells motile in the presence of the substrate; -, cells not motile in the presence of the substrate.

\footnotetext{
* Corresponding author.

$\dagger$ Present address: Microbiology, University of Minnesota Health Center, Box 196, Minneapolis, MN 55455-0312.
}

growth on these compounds produces swollen, pleomorphic cells in $X$. autotrophicus and $X$. flavus but scarcely in $X$. agilis. This characteristic has been used to differentiate Xanthobacter species (10). Cells of $X$. flavus produce large amounts of poly- $\beta$-hydroxybutyrate as a carbon reserve (10), and we assume that this compound serves as a carbon and energy source for flagellum synthesis and motility when cells are incubated in a medium lacking usable carbon. The nitrogen source used $\left(\mathrm{NH}_{3}, \mathrm{NO}_{3}\right.$, or $\left.\mathrm{N}_{2}\right)$ had no effect on motility.

When cultures were grown with $0.1 \% n$-propanol as the sole carbon source, approximately $20 \%$ of the $X$. flavus H4-14 cells and $35 \%$ of the $X$. flavus $301^{\mathrm{T}}\left(=\mathrm{DSM} 338^{\mathrm{T}}\right)(\mathrm{T}$

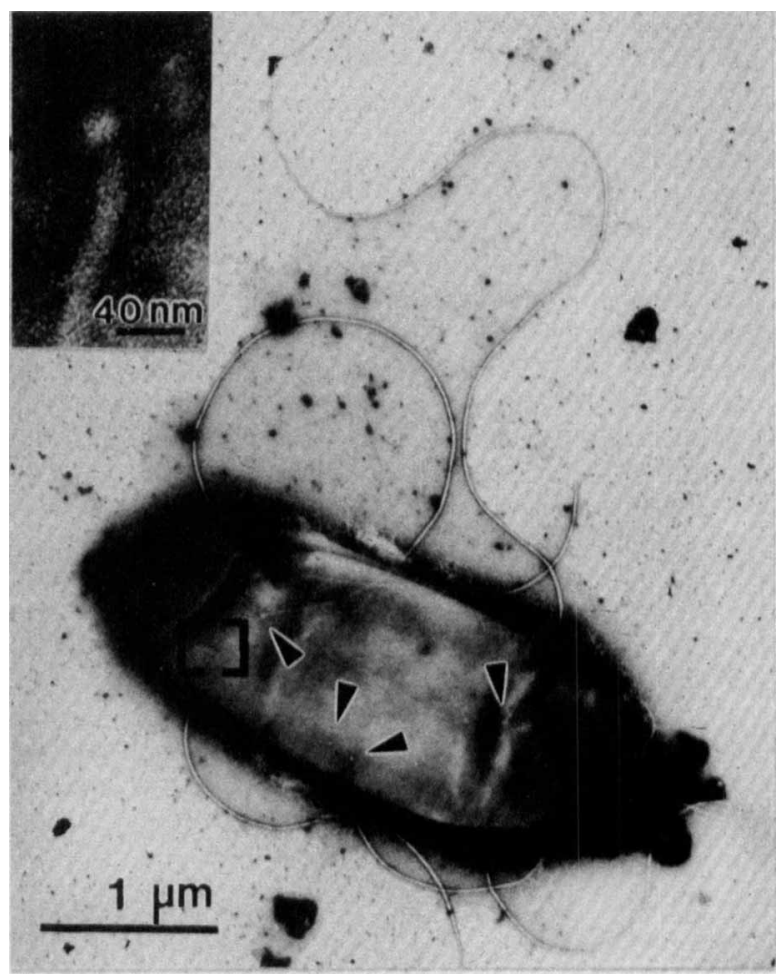

FIG. 1. X. flavus H4-14, showing flagellum insërtions (arrows). (Inset) Magnified view of the region in brackets, showing flagellum insertion. Samples were negatively stained by using the singlecarbon-layer technique of Valentine et al. (9) and were viewed by using a JEOL model 100CXII transmission electron microscope. 


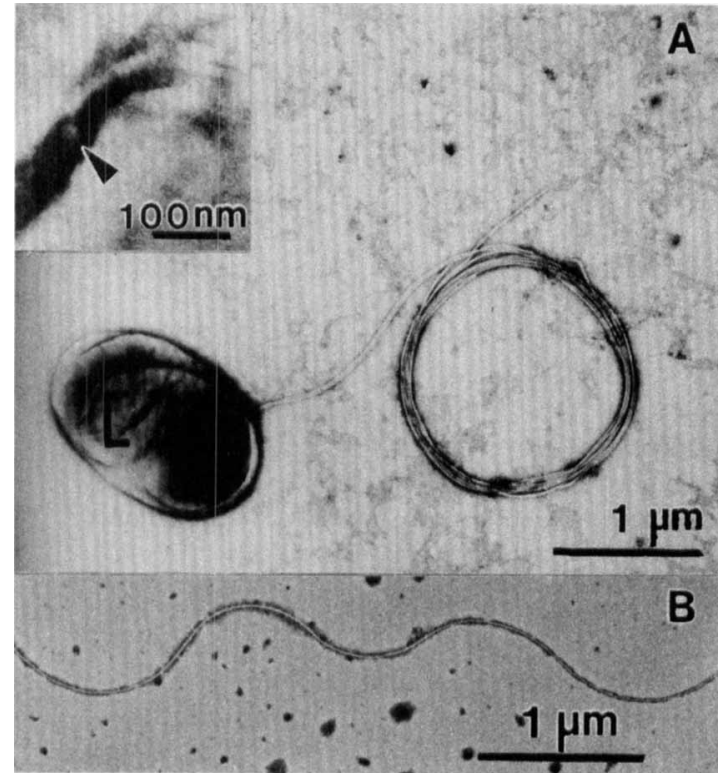

FIG. 2. (A) $X$. flavus $301^{\mathrm{T}}$ cell with two coiled flagella. (Inset) Magnified view of the region in brackets, showing insertion of one of the flagella. (B) Isolated flagellum of $X$. flavus $301^{\mathrm{T}}$ forming a wavelength pattern. For the methods which we used, see the legend to Fig. 1 .

= type strain) cells were motile throughout the log phase by means of retarded peritrichous flagella (Fig. 1 and 2). Motile cells of $X$. flavus 25a, SA12, and MA10 (3) were also observed during growth on propanol; however, no motile

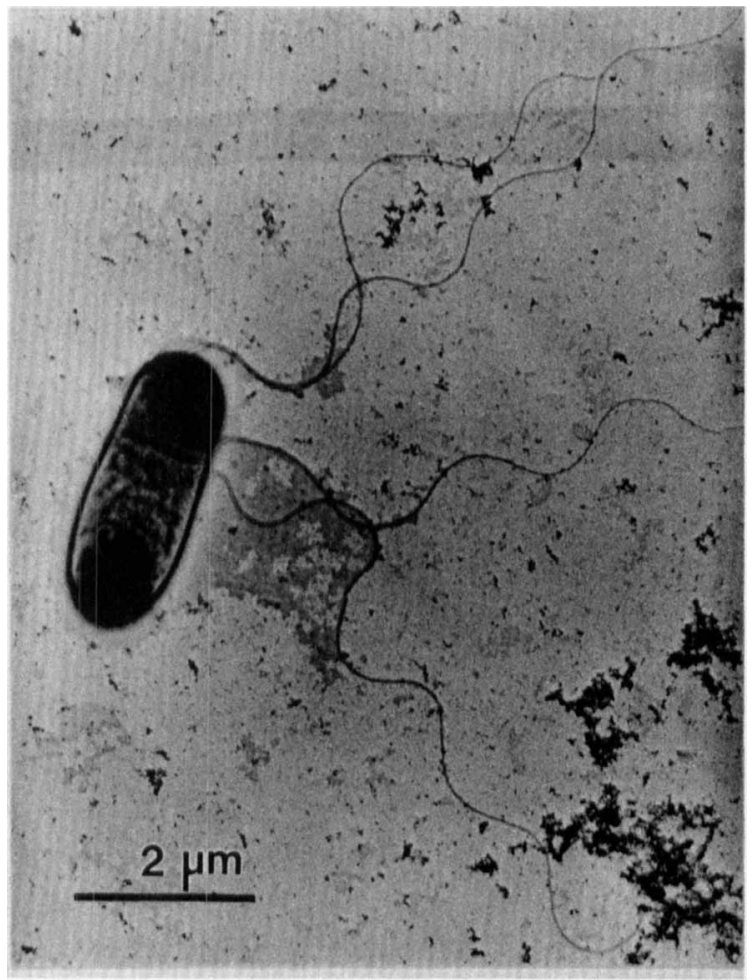

FIG. 3. $X$. agilis $\mathrm{SA} 35^{\mathrm{T}}$ cell with four peritrichous flagella. For the methods which we used see the legend to Fig. 1.
TABLE 2. Comparison of the flagella of $X$. flavus and $X$. agilis ${ }^{a}$

\begin{tabular}{lcccc}
\hline \multicolumn{1}{c}{ Strain } & No. & $\begin{array}{c}\text { Diam } \\
(\mathrm{nm})\end{array}$ & $\begin{array}{c}\text { Length } \\
(\mu \mathrm{m})^{b}\end{array}$ & $\begin{array}{c}\text { Wavelength } \\
(\mu \mathrm{m})^{c}\end{array}$ \\
\hline$X$. agilis SA35 $^{\mathrm{T}}$ & $2-5$ & 14.2 & 9.2 & $2.0(0.26)$ \\
$X$. flavus $301^{\mathrm{T}}$ & $1-7$ & 14.5 & 14.0 & $2.5(0.37)$ \\
$X$. flavus $\mathrm{H}^{\mathrm{N}}-14$ & $2-7$ & 14.2 & 13.0 & $2.2(0.7)$ \\
\hline
\end{tabular}

${ }^{a} X$. flavus $301^{\mathrm{T}}$ and $\mathrm{H} 4-14$ cells were cultured on medium containing $0.1 \%$ $n$-propanol, and $X$. agilis $\mathrm{SA}^{3} 5^{\mathrm{T}}$ cells were cultured on medium containing $0.1 \%$ fumarate. Data for $X$. autotrophicus $7 \mathrm{cSF}$ are not given because of inconsistent flagellation. All cells with more than one flagellum were peritrichous. When a cell had only one flagellum, no specific placement of the flagellum was apparent.

${ }^{b}$ Longest observed filament length.

${ }^{c}$ Mean (standard deviation) of the wavelength, when it was observed.

cells were found in cultures of $X$. flavus SA14 and CB2 (3) when these organisms were cultured under similar conditions. Under culture conditions which resulted in nonmotile cells (e.g., growth in the presence of succinate), no cells possessed fiagella.

We found that up to $50 \%$ of the cells of $X$. autotrophicus $7 \mathrm{cSF}$ (= DSM 2267) (a slime-reduced mutant of type strain 7c [= DSM 432]) were motile in the very early log phase when cultures were grown with $0.1 \% n$-propanol as the sole carbon source in the absence of tricarboxylic acid cycle intermediates. However, for unknown reasons, production of motile cells was not always reproducible. $X$. autotrophicus $7 \mathrm{c}^{\mathrm{T}}, \mathrm{JW} 33$ (reference strain [= DSM 1618]), JW21, and JW4 were nonmotile and nonflagellated under all of the growth phase and carbon source conditions tested (data not shown). Nevertheless, it is possible that strains of $X$. autotrophicus may become motile if certain conditions exist, including a reduction in the amount of slime produced.

The motility of $X$. agilis was not dependent on the carbon source since all growing cultures contained motile cells (Table 1). X. agilis has retarded peritrichous flagella (1) (Fig. 3).

The flagellation of $X$. flavus and the flagellation of $X$. agilis were comparable with respect to number, position, diameter, length, and wavelength of the flagella (Table 2). Thus, the type of flagellation cannot be used as a taxonomic tool. However, the motility of $X$. flavus differs from the motility of $X$. agilis in that $X$. agilis is motile irrespective of the carbon source. In light of this, the presence or absence of motility should not be used any longer as a main criterion for assigning Xanthobacter isolates to one of the three Xanthobacter species.

This work was funded in part by a Biotechnology Grant from The University of Georgia Office of the Vice President for Research.

$X$. flavus H4-14 (4) was kindly provided by Mary Lidstrom.

\section{REFERENCES}

1. Aragno, M., A. Walther-Mauruschat, F. Mayer, and H. G. Schlegel. 1977. Micromorphology of gram-negative hydrogen bacteria. I. Cell morphology and flagellation. Arch. Microbiol. 114:93-100.

2. Jenni, B., and M. Aragno. 1987. Xanthobacter agilis sp. nov., a motile, dinitrogen-fixing, hydrogen-oxidizing bacterium. Syst. Appl. Microbiol. 9:254-257.

3. Jenni, B., M. Aragno, and J. K. W. Wiegel. 1987. Numerical analysis and DNA-DNA hybridization studies on Xanthobacter and emendation of Xanthobacter flavus. Syst. Appl. Microbiol. 9:247-253.

4. Lidstrom-O'Conner, M. E., G. L. Fulton, and A. E. Wopat. 1983. "Methylobacterium ethanolicum": a syntrophic associa- 
tion of two methylotrophic bacteria. J. Gen. Microbiol. 129: 3139-3148.

5. Malik, K. A., and D. Claus. 1979. Xanthobacter flavus, a new species of nitrogen-fixing hydrogen bacteria. Int. J. Syst. Bacteriol. 29:283-287.

6. Meijer, W. G., L. M. Croes, B. Jenni, L. G. Lahmicke, M. E. Lidstrom, and L. Dijkhuizen. 1990. Characterization of Xanthobacter strains H4-14 and 25a and enzyme profiles after growth under autotrophic and heterotrophic conditions. Arch. Microbiol. 153:360-367.

7. Reding, H. K., P. Hartel, and J. Wiegel. 1990. Xanthobacter as a rhizosphere organism of rice, p. 431. In P. M. Gresshoff, L. E. Roth, G. Stacy, and W. E. Newton (ed.), Nitrogen fixation: achievements and objectives. Proceedings of the 8th International Congress on Nitrogen Fixation. Chapman and Hall, New York.

8. Reding, H. K., P. G. Hartel, and J. Wiegel. 1991. Effect of Xanthobacter, isolated and characterized from rice roots, on growth of wetland rice. Plant Soil 138:221-229.

9. Valentine, R. C., B. M. Shapiro, and E. R. Stadtmen. 1968. Regulation of glutamine synthetase. XII. Electron microscopy of the enzyme from Escherichia coli. Biochemistry 7:2143-2152.

10. Wiegel, J. 1992. The genus Xanthobacter, p. 2365-2383. In A. Balows, H. G. Trüper, M. Dworkin, W. Harder, and K. H. Schleifer (ed.), The prokaryotes. A handbook on the biology of bacteria. Ecophysiology, isolation, identification, Application, 2nd ed. Springer-Verlag, New York.

11. Wiegel, J., D. Wilke, J. Baumgarten, R. Opitz, and H. G. Schlegel. 1978. Transfer of the nitrogen-fixing hydrogen bacterium Corynebacterium autotrophicum Baumgarten et al. to Xanthobacter gen. nov. Int. J. Syst. Bacteriol. 28:573-581.

12. Wiegel, J. K. W., and H. G. Schlegel. 1984. Xanthobacter autotrophicus, p. 325-333. In N. R. Krieg and J. G. Holt (ed.), Bergey's manual of systematic bacteriology, vol. 1. The Williams \& Wilkins Co., Baltimore. 